\title{
Body Composition Features in Different Playing Position of Professional Team Indoor Players: Basketball, Handball and Futsal
}

\author{
Características Antropométricas en Función del Puesto en Jugadores \\ Profesionales de Equipo: Baloncesto, Balonmano y Fútbol Sala
}

\begin{abstract}
Domingo Jesús Ramos-Campo*,**; Fernando Martínez Sánchez*; Paula Esteban García*; Jacobo Ángel Rubio Arias*; Antonio Bores Cerezal ${ }^{* * *}$; Vicente Javier Clemente-Suarez ${ }^{* * * *}$ \& José Fernando Jiménez Díaz*
\end{abstract}

RAMOS-CAMPO, D. J.; MARTÍNEZ-SÁNCHEZ, F.; ESTEBAN-GARCÍA, P.; RUBIO-ARIAS, J. A.; BORES, C. A.; CLEMENTE-SUAREZ, V. J. \& JIMÉNEZ-DIAZ, J. F. Body composition features in different playing position of professional team indoor players: basketball, handball and futsal. Int. J. Morphol., 32(4):1316-1324, 2014.

SUMMARY: The aim of the present research was to analyze the body composition (BC) and the differences in BC among different playing position in professional basketball, handball and futsal players. BC was assessed in 70 professional indoor team sport players. Players were divided in 4 groups depending on the playing position: group 1, point guard, center/wings and defense; group 2, shooting guard/small forward, handed and midfielder; group 3, power forward/center, pivot and forward; and group 4 goalkeeper. Significant differences between playing positions in basketball in body mass (BM), height, proteins, minerals and arms, legs and trunk BM were found. In handball, significant differences between center/wings and pivot in BM and muscle mass, and between goalkeepers and handed in percentage of fat were measured. Significant differences were also found in BM of each playing position groups in the three sports and in arms and legs BM in groups 1 and 2, and trunk BM and height in group 2. Group 3 presented significant differences between futsal and basketball in skeletal muscle mass and trunk BM, and between basketball and handball in left leg BM and total BM. In group 4 significant differences in BM, height and trunk and leg BM between futsal and handball were found. BC in indoor team sports depend on the playing position and the sport discipline, the BC being result of the specific game actions of each playing position.

KEY WORDS: Fat mass; Height; Performance; Body mass.

\section{INTRODUCTION}

The optimal physical performance depends on several factors as genetic characters, healthy, diet, environment, training schedule, moods and body composition (BC) (Villa et al., 2009). BC is one of the most important pillars of the kinanthropometry, closely related with the athlete's ability to reach the highest performance (Porta et al., 1995). The study of BC includes different corporal regions analyzes (Wang et al., 1995) and actually several methods with high accuracy and reliability as the dual-energy X-ray absorptiometry (DXA) or the dual-photon absorptiometry (DPA) are used for this purpose (Williams et al., 1995). Nowadays there are other valid instruments extensively used as the electrical bioimpedance (BIA) that presented a high correlation with the DXA (Gibson et al., 2008; Sun et al., 2005).
$\mathrm{BC}$ plays a crucial role in the physical team indoor sport performance: an excess of fat mass acts as a dead body mass in activities where the body must be repeatedly lifted during locomotion and jumping, decreasing performance and increasing energy demands. However, muscle-skeletal mass is an indicator of sports performance (Vila Suárez et al., 2008), because it contributes to the energy production during high-intensity activities and provides absolute strength to athletes (Vila Suárez et al.). BC has a direct association to physical performance in intermittent team indoor sports due to they combine frequent short intense efforts with variables periods of low intensity activity (Vila Suárez et al.; Wallace \& Cardinale, 1997). Previously, researches focused on BC attempted to analyze the physical and anthropometrical characteristics of basketball (Popovic et

\footnotetext{
* Laboratory of Physical Performance and Readaptation Injuries, University of Castilla-La Mancha; Toledo, Spain.

** Department of Physical Activity and Sport Science. Sport Science Faculty. Catholic University of Murcia, Murcia, Spain.

**** Real Federación Española de Fútbol.

***** Department of Physical Activity and Sport Science. Sport Science Faculty. University of Castilla La Mancha, Toledo. Spain.
} 
RAMOS-CAMPO, D. J.; MARTÍNEZ-SÁNCHEZ, F.; ESTEBAN-GARCÍA, P.; RUBIO-ARIAS, J. A.; BORES, C. A.; CLEMENTE-SUAREZ, V. J. \& JIMÉNEZ-DIAZ, J. F. Body composition features in different playing position of professional team indoor players: basketball, handball and futsal. Int. J. Morphol., 32(4):1316-1324, 2014.

al., 2013; Sallet et al., 2005), handball (Chaouachi et al., 2009) and football players (Avelar et al., 2008; Ferreira et al., 2009). In basketball and handball, players' body mass was the limiting factor that determined their playing position (Drinkwater et al., 2007; Hoare, 2000).

Specifically in basketball, results showed that center were taller, heavier and presented a higher percentage of body fat than forwards and point guard (Lamonte et al., 1999). Moreover, in handball back centers, goalkeepers and back wingers were heavier than wingers and forward center (Moncef et al., 2012). Also in soccer players differences were found between playing positions, especially in body mass and height between the goalkeeper and the rest of playing positions (Silvestre et al., 2006). However, to the best of our knowledge, there is no research that has studied body composition in futsal players, or studies that provide normative data of body segmental composition (legs, trunk and arms) and differences among playing positions in indoor team sports.

Therefore, the purpose of the present study was to analyze the body composition and the differences in body composition among playing position in professional basketball, handball and futsal players. It was hypothesized that differences among playing positions would be detected.

\section{MATERIAL AND METHOD}

Design. A cross-sectional experimental design was conducted to analyze the BC of professional male basketball, handball and futsal players according to their playing position. Prior to participation, the experimental procedures were explained to all the participants, who gave their voluntary written informed consent. The study was designed in compliance with the recommendations for clinical research of the World Medical Association Helsinki's Declaration. The protocol was reviewed and approved by the local ethics committee.

Participants. To confirm the hypothesis of the study 70 professional male athletes were analyzed during the regular season. Players were 25 basketball Spanish professional national league (ACB) players (Age: 27.3 \pm 1.2 years; height: $196.57 \pm 1.9 \mathrm{~cm}$; body mass: $96.1 \pm 3.1 \mathrm{~kg}$; experience in ACB: $6.0 \pm 0.5$ years); 17 futsal Spanish professional national league (LNFS) players (Age: 29.0 \pm 2.9 years; height: $175.5 \pm 4.4 \mathrm{~cm}$; body mass: $89.4 \pm 7.2 \mathrm{~kg}$; experience in LNFS: $4.0 \pm 0.6$ years); and 28 handball Spanish professional national league (ASOBAL) players (Age: $28.4 \pm 0.9$ years; height: $191.6 \pm 1.4 \mathrm{~cm}$; body mass: $97.1 \pm 2.3 \mathrm{Kg}$; experience in ASOBAL: $6.2 \pm 1.1$ years). Players were also divided in 4 different groups depending on the playing position. The characteristics of the fourth groups are showed in Table I.

Methodology. BC was assessed with a segmental multifrequency bioimpedance analyzer (InBody 720, Biospace Co. Ltd., Seoul, South Korea) with measurements obtained as described by the manufacturer. InBody 720 is a multifrequency impedance plethysmograph body composition analyzer, which uses an eight-point tactile electrode method to take readings from the body. It measures resistance at five specific frequencies $(1 \mathrm{kHz}, 50 \mathrm{kHz}, 250 \mathrm{kHz}, 500 \mathrm{kHz}$, and 1 $\mathrm{MHz})$ and reactance at three specific frequencies $(5 \mathrm{kHz}$, $50 \mathrm{kHz}$, and $250 \mathrm{kHz}$ ) on each of five segments (right arm, left arm, trunk, right leg and left leg). Bioelectricalimpedance analysis is one of the methods available for measuring body composition in sporting populations and InBody provides a precise analysis for body development

Table I. Body composition characteristics of players depending on the sport modality and the playing position

\begin{tabular}{|c|c|c|c|c|c|}
\hline & & Group 1 & Group 2 & Group 3 & Group 4 \\
\hline Basketball & $=25)$ & Point guard $(n=5)$ & $\begin{array}{l}\text { Shooting guard/Small } \\
\text { forward }(n=9)\end{array}$ & $\begin{array}{l}\text { Power forw ard/Center } \\
\qquad(\mathrm{n}=11)\end{array}$ & - \\
\hline Handball ( $\mathrm{n}$ & & Centre/Wings $(n=7)$ & Handed $(n=12)$ & Pivot $(n=5)$ & Goalkeeper $(n=4)$ \\
\hline Futsal $(n=1$ & & Back $(n=3)$ & Midfielder $(n=6)$ & Forward $(n=5)$ & Goalkeeper $(n=3)$ \\
\hline Basketball & Age (years) & $25.20 \pm 7.01$ & $24.67 \pm 4.03$ & $26.73 \pm 4.38$ & \\
\hline & Body mass (Kg) & $83.26 \pm 5.71$ & $91.08 \pm 7.40$ & $109.94 \pm 10.80$ & \\
\hline & Height $(\mathrm{cm})$ & $184.88 \pm 1.69$ & $194.62 \pm 5.70$ & $207.45 \pm 5.73$ & \\
\hline Handball & Age (years) & $26.57 \pm 2.64$ & $28.00 \pm 3.22$ & $28.25 \pm 6.40$ & $30.67 \pm 3.79$ \\
\hline & Body mass (Kg) & $87.84 \pm 5.60$ & $95.18 \pm 8.57$ & $106.65 \pm 14.73$ & $98.90 \pm 17.69$ \\
\hline & Height $(\mathrm{cm})$ & $187.57 \pm 4.50$ & $191.42 \pm 7.51$ & $194.25 \pm 4.86$ & $193.00 \pm 6.93$ \\
\hline Futsal & Age (years) & $25.00 \pm 4.58$ & $24.33 \pm 5.13$ & $26.80 \pm 3.96$ & $23.00 \pm 2.65$ \\
\hline & Body mass (Kg) & $76.17 \pm 9.60$ & $72.12 \pm 4.05$ & $80.72 \pm 12.21$ & $80.67 \pm 5.63$ \\
\hline & Height $(\mathrm{cm})$ & $182.67 \pm 8.33$ & $174.77 \pm 4.61$ & $176.86 \pm 3.83$ & $179.67 \pm 5.77$ \\
\hline
\end{tabular}


status and balance; analysis of items by segment and different body indexes are used as essential data for exercise prescription. The reliability of bioelectrical-impedance analysis compared to other body composition measurement methods, like DXA, has been successfully demonstrated (Shafer et al., 2009).

In order to carry out the tests, the participants stood upright on foot electrodes on the instrument platform, with legs and thighs apart and arms not touching the torso. They were barefooted and without excess clothing. Four-foot electrodes were used, two of which were oval-shaped and two heel-shaped, and prior to testing both the skin and the electrodes were cleaned and dried. Participants were asked to grip the palm and thumb electrodes (two of each electrode per athlete). Body height was measured using Seca 700 (Seca Ltd., Germany) scale. Body composition parameters were determined directly. Data were electronically imported to Excel using Lookin'Body 3.0 software. The system was calibrated prior to each testing session. The following parameters were analyzed: (i) body mass (kg), (ii) height (cm), (iii) body mass index (BMI) (kg/m2), (iv) skeletal muscle mass (SMM) (kg), (v) intracellular water (l), (vi) extracellular water (l), (vii) proteins $(\mathrm{kg})$, (viii) minerals $(\mathrm{kg})$, (ix) body fat $(\mathrm{kg}),(\mathrm{x})$ right arm body mass $(\mathrm{kg})$, (xi) left arm body mass $(\mathrm{kg})$, (xii) trunk body mass $(\mathrm{kg})$, (xiii) right leg body mass $(\mathrm{kg})$, and (xiv) left leg body mass (kg).

Statistical analysis. Data obtained were statistically treated using the SPSS (v20.0; SPSS, Inc., Chicago, IL, USA) statistical program. Normality of data was tested with the Shapiro-Wilk test. For parametric data, two factors (playing position $\mathrm{x}$ sport) ANOVA was used to determine significantly differences in $\mathrm{BC}$ among playing positions with a Bonferroni post hoc comparison. For non parametric data, a Mann- Whitney U test was used to compare average values and Kolmogorov-Smirnov $\mathrm{Z}$ test was used to determinate the significant differences between variables. The level of significance was set at $\mathrm{p}<0.05$.

\section{RESULTS}

Basketball center player presented significantly higher body mass, height, SMM, intracellular and extracellular water, proteins, minerals and arms, legs and trunk body mass than shooting guard/small forward and point guard (Table II).

In handball, pivot presented higher SMM, left arm body mass and intracellular water than centre/back (Table III).

In futsal players no significant differences were found (Table IV).

Handball players of group 1 had higher values of body mass and SMM and basketball players' presented the higher fat mass values. We also found significant differences between the three sports in extracellular water; legs and arms body mass variables (Fig. 1).

Table II. Body composition data in basketball players.

\begin{tabular}{|c|c|c|c|}
\hline & Group 1 & Group 2 & Group 3 \\
\hline Body mass (Kg) & $83.26 \pm 5.71 * * *$ & $91.08 \pm 7.40 \ddagger+\ddagger$ & $109.94 \pm 10.80$ \\
\hline Height (cm) & $184.88 \pm 1.69 * * * \dagger$ & $194.62 \pm 5.70 \div+\neq$ & $207.45 \pm 5.73$ \\
\hline BMI $\left(\mathrm{kg} / \mathrm{m}_{2}\right)$ & $23.41 \pm 1.05$ & $24.28 \pm 1.56$ & $26.36 \pm 1.95$ \\
\hline SMM (Kg) & $38.45 \pm 0.35 * * *$ & $48.34 \pm 3.75 \ddagger+\ddagger$ & $56.19 \pm 7.29$ \\
\hline Intracellular water (l) & $31.00 \pm 0.28 * * *$ & $38.62 \pm 2.86 \neq+\ddagger$ & $44.63 \pm 5.59$ \\
\hline Extracellular water (l) & $19.00 \pm 0.14 * * *$ & $20.79 \pm 1.63+4+$ & $27.20 \pm 3.41$ \\
\hline Proteins (Kg) & $13.40 \pm 0.14 * * *$ & $16.70 \pm 1.27 \ddagger \ddagger$ & $19.29 \pm 2.42$ \\
\hline Minerals (Kg) & $4.72 \pm 0.14 * * *$ & $5.87 \pm 0.43 \ddagger \neq \neq$ & $6.98 \pm 0.79$ \\
\hline Fat mass (Kg) & $13.25 \pm 5.30$ & $10.24 \pm 2.07$ & $14.48 \pm 4.91$ \\
\hline Fat mass $(\%)$ & $16.15 \pm 5.44$ & $10.80 \pm 1.85$ & $12.93 \pm 4.26$ \\
\hline Right arm body mass (Kg) & $4.16 \pm 0.34 * * *$ & $5.05 \pm 0.51 \ddagger \neq$ & $5.98 \pm 0.89$ \\
\hline Left arm body mass $(\mathrm{Kg})$ & $3.97 \pm 0.23 * * *$ & $4.90 \pm 0.36 \ddagger \neq \neq$ & $5.95 \pm 0.92$ \\
\hline Trunk body mass (Kg) & $30.70 \pm 1.27 * *$ & $36.06 \pm 2.44 \ddagger$ & $41.71 \pm 5.05$ \\
\hline Right leg body mass (Kg) & $10.72 \pm 0.25 * * *$ & $13.89 \pm 1.33 \ddagger \ddagger$ & $15.87 \pm 2.03$ \\
\hline Left leg body mass (Kg) & $10.67 \pm 0.18 * * *$ & $13.73 \pm 1.25 \neq+$ & $15.87 \pm 1.93$ \\
\hline
\end{tabular}

BMI: body mass index; SMM: skeletal muscle mass.

* Significant differences between group 1 and 3 ; ${ }^{*} \mathrm{p}<0.05 ; * * \mathrm{p}<0.01$; *** $<<0.001$.

$\dagger$ Significant differences between group 1 and $2 ; \dagger \mathrm{p}<0.05 ; \dagger \uparrow \mathrm{p}<0.01$; $\uparrow \dagger \mathrm{p}<0.001$.

$\ddagger$ Significant differences between group 2 and $3 ; \neq \mathrm{p}<0.05 ; \ddagger \neq \mathrm{p}<0.01 ; \ddagger+\downarrow \mathrm{p}<0.001$. 
RAMOS-CAMPO, D. J.; MARTÍNEZ-SÁNCHEZ, F.; ESTEBAN-GARCÍA, P.; RUBIO-ARIAS, J. A.; BORES, C. A.; CLEMENTE-SUAREZ, V. J. \& JIMÉNEZ-DIAZ, J. F. Body composition features in different playing position of professional team indoor players: basketball, handball and futsal. Int. J. Morphol., 32(4):1316-1324, 2014.

Table III. Body composition data in handball players.

\begin{tabular}{lcccc}
\hline & Group 1 & Group 2 & Group 3 & Group 4 \\
\cline { 2 - 5 } Body mass (Kg) & $87.84 \pm 5.60^{*}$ & $95.18 \pm 8.57$ & $106.65 \pm 14.73$ & $98.90 \pm 17.69$ \\
Height (cm) & $187.57 \pm 4.50$ & $191.42 \pm 7.51$ & $194.25 \pm 4.86$ & $193.00 \pm 6.93$ \\
BMI (kg/m2) & $24.97 \pm 1.25$ & $26.20 \pm 1.64$ & $28.43 \pm 5.40$ & $26.40 \pm 2.82$ \\
SMM (Kg) & $43.74 \pm 3.54 *$ & $48.62 \pm 5.14$ & $53.48 \pm 2.63$ & $46.27 \pm 10.36$ \\
Intracellular water (l) & $35.07 \pm 2.71 *$ & $38.82 \pm 3.93$ & $42.55 \pm 1.99$ & $37.03 \pm 7.94$ \\
Extracellular water (I) & $20.79 \pm 1.63$ & $23.11 \pm 2.52$ & $24.73 \pm 1.32$ & $22.10 \pm 4.46$ \\
Proteins (Kg) & $15.19 \pm 1.18$ & $16.79 \pm 1.70$ & $18.38 \pm 0.87$ & $16.00 \pm 3.42$ \\
Minerals (Kg) & $5.17 \pm 0.47$ & $5.81 \pm 0.62$ & $6.36 \pm 0.28$ & $5.57 \pm 1.34$ \\
Fat mass (Kg) & $11.64 \pm 3.34$ & $10.67 \pm 3.34$ & $14.63 \pm 10.79$ & $18.17 \pm 0.76$ \\
Fat mass (\%) & $13.24 \pm 3.69$ & $11.27 \pm 3.39$ & $12.93 \pm 7.45$ & $18.67 \pm 2.57$ \\
Right arm body mass (Kg) & $4.67 \pm 0.43$ & $5.21 \pm 0.68$ & $5.79 \pm 0.31$ & $4.93 \pm 1.16$ \\
Left arm body mass (Kg) & $4.49 \pm 0.41 *$ & $5.19 \pm 0.61$ & $5.75 \pm 0.41$ & $4.79 \pm 1.05$ \\
Trunk body mass (Kg) & $33.61 \pm 2.28$ & $37.03 \pm 3.65$ & $40.48 \pm 2.03$ & $35.43 \pm 6.26$ \\
Right leg body mass (Kg) & $11.90 \pm 1.07$ & $12.93 \pm 1.51$ & $13.44 \pm 1.05$ & $12.62 \pm 2.06$ \\
Left leg body mass (Kg) & $11.80 \pm 1.03$ & $12.85 \pm 1.52$ & $13.43 \pm 0.89$ & $12.50 \pm 1.98$ \\
\hline
\end{tabular}

BMI: body mass index; SMM: skeletal muscle mass.

* Significant differences between group 1 and $3 ; * \mathrm{p}<0.05 ; * * \mathrm{p}<0.01 ; * * \mathrm{p}<0.001$.

Table IV. Body composition data in futsal players.

\begin{tabular}{lrrrr}
\hline & Group 1 & Group 2 & Group 3 & \multicolumn{1}{c}{ Group 4 } \\
\cline { 2 - 5 } Body mass (Kg) & $76.17 \pm 9.60$ & $72.12 \pm 4.05$ & $80.72 \pm 12.21$ & $80.67 \pm 5.63$ \\
Height (cm) & $182.67 \pm 8.33$ & $174.77 \pm 4.61$ & $176.86 \pm 3.83$ & $179.67 \pm 5.77$ \\
BMI (kg/m) & $22.87 \pm 1.31$ & $23.53 \pm 0.93$ & $25.74 \pm 1.01$ & $25.03 \pm 1.31$ \\
SMM (Kg) & $42.30 \pm 3.03$ & $48.62 \pm 2.14$ & $48.72 \pm 2.35$ & $48.50 \pm 3.03$ \\
Intracellular water (l) & $35.34 \pm 2.17$ & $36.45 \pm 1.54$ & $36.85 \pm 1.68$ & $35.56 \pm 2.17$ \\
Extracellular water (I) & $21.56 \pm 1.43$ & $23.88 \pm 1.01$ & $26.96 \pm 0.75$ & $25.04 \pm 1.43$ \\
Proteins (Kg) & $17.81 \pm 1.14$ & $18.28 \pm 0.81$ & $19.20 \pm 0.60$ & $17.76 \pm 1.14$ \\
Minerals (Kg) & $6.13 \pm 0.42$ & $6.23 \pm 0.30$ & $5.77 \pm 0.33$ & $5.92 \pm 0.42$ \\
Fat mass (Kg) & $9.65 \pm 2.66$ & $10.47 \pm 1.88$ & $13.76 \pm 2.06$ & $11.89 \pm 2.66$ \\
Fat mass (\%) & $12.70 \pm 2.33$ & $13.57 \pm 1.65$ & $16.45 \pm 1.80$ & $14.58 \pm 2.33$ \\
Right arm body mass $(\mathbf{K g})$ & $4.80 \pm 0.39$ & $5.34 \pm 0.27$ & $5.50 \pm 0.3$ & $5.10 \pm 0.39$ \\
Left arm body mass $(\mathbf{K g})$ & $4.87 \pm 0.39$ & $5.38 \pm 0.19$ & $5.48 \pm 0.29$ & $4.97 \pm 0.37$ \\
Trunk body mass $(\mathbf{K g})$ & $32.57 \pm 1.05$ & $39.61 \pm 1.76$ & $39.88 \pm 1.36$ & $38.77 \pm 2.05$ \\
Right leg body mass $(\mathbf{K g})$ & $12.83 \pm 1.02$ & $15.84 \pm 0.72$ & $15.99 \pm 0.79$ & $13.10 \pm 1.02$ \\
Left leg body mass $(\mathbf{K g})$ & $12.93 \pm 0.99$ & $15.68 \pm 0.70$ & $16.03 \pm 0.76$ & $13.20 \pm 0.99$ \\
\hline BMI & & &
\end{tabular}

BMI: body mass index; SMM: skeletal muscle mass.

Group 2 players had significant differences in variables of height; trunk and legs body mass between futsal and basketball and between futsal and handball. Basketball players presented the highest fat mass and handball players were the heaviest players (Fig. 2).

Futsal players of group 3 obtained significantly lower values of SMM, intracellular water and trunk body mass than basketball players. Furthermore, the left leg body mass of handball player was significantly heavier than basketball players, and handball and basketball players obtained significantly higher values in body mass than futsal players. Basketball players had the highest SMM and body mass, and futsal players the highest fat mass (Fig. 3).

We found higher values in body mass and fat mass in handball than futsal goalkeepers, which presented higher SMM. Variables of trunk and legs body mass and height were significantly higher in futsal than handball goalkeepers. In the opposite way, handball goalkeepers had a significantly higher body mass than futsal goalkeepers (Fig. 4). 


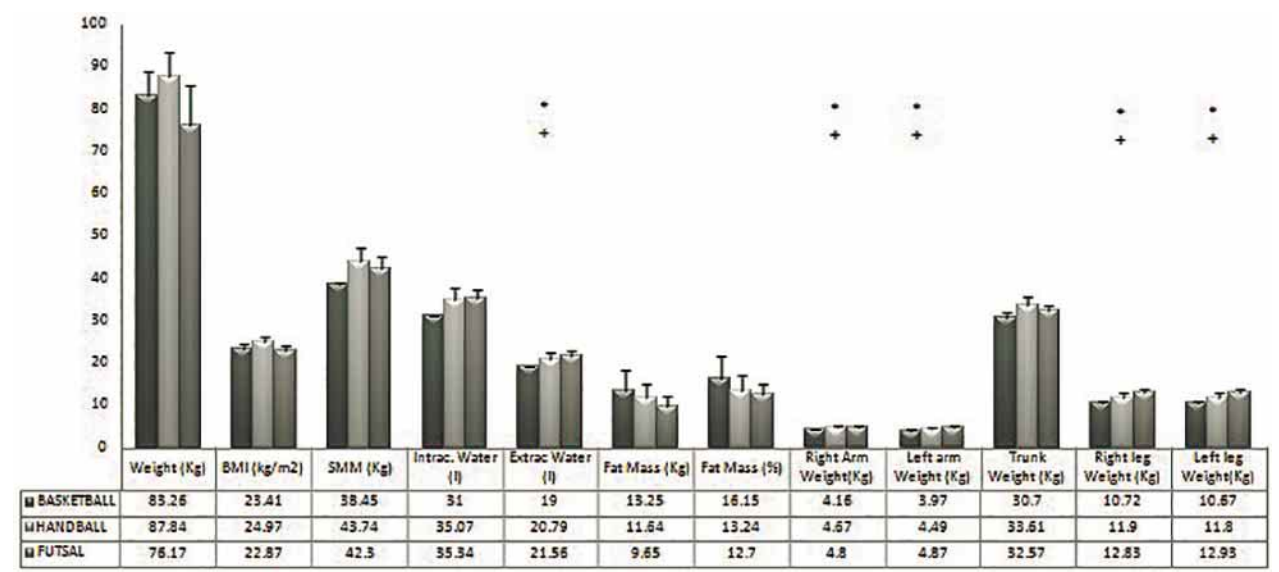

Fig. 1. Body composition of group 1 players in basketball, handball and futsal.

l= litter; Kg= Kilogram; $m=$ meter; Intrac= Intracellular; Extrac= Extracellular.

*Significant differences between basketball and futsal, $\mathrm{p}<0.05$

$\dagger$ Significant differences between handball and futsal, $\mathrm{p}<0.05$.

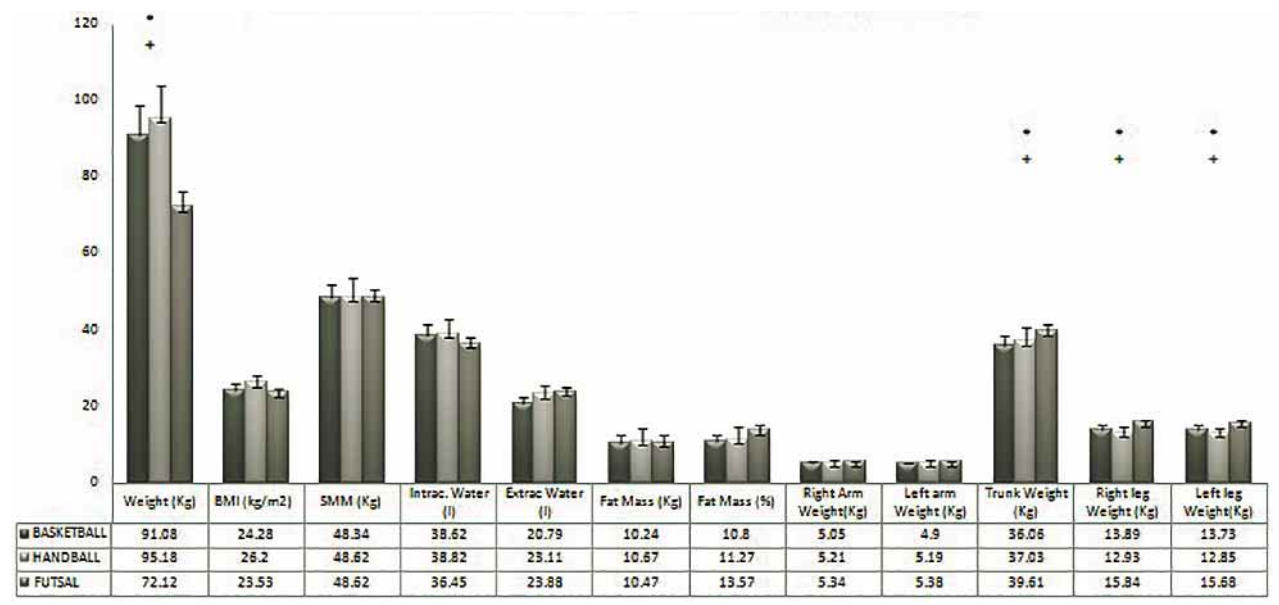

Fig. 2. Body composition of group 2 players in basketball, handball and futsal.

l= litter; $\mathrm{Kg}=$ Kilogram; $\mathrm{m}=$ meter; Intrac= Intracellular; Extrac= Extracellular.

* Significant differences between basketball and futsal, $\mathrm{p}<0.05$.

$\dagger$ Significant differences between handball and futsal, $\mathrm{p}<0.05$.

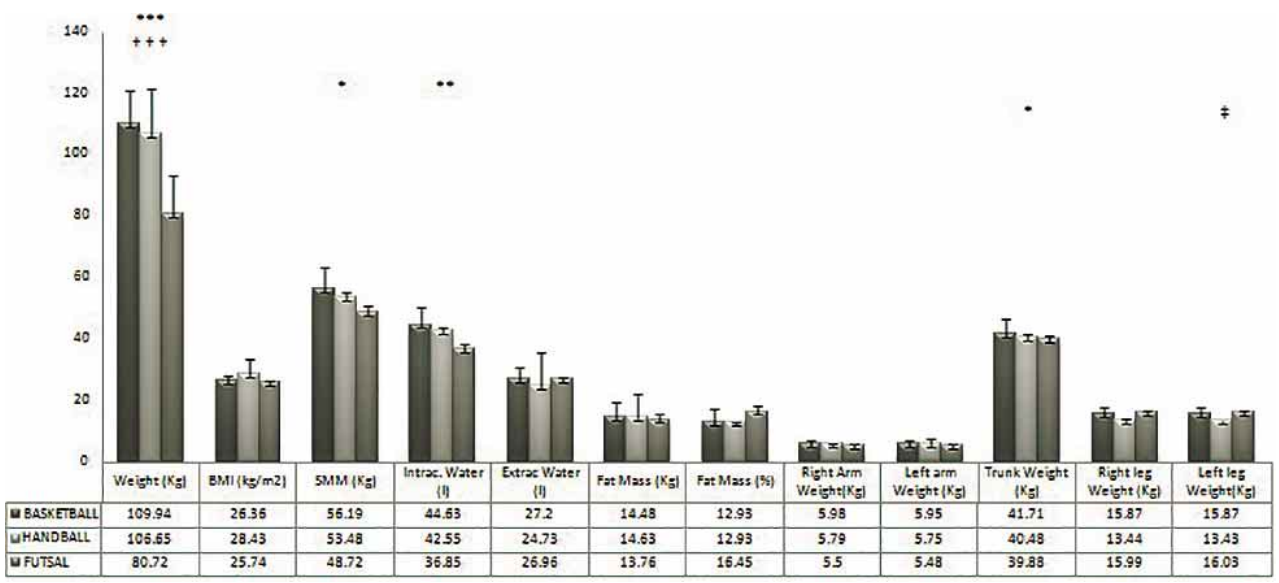

Fig. 3. Body composition of group 3 players in basketball, handball and futsal.

$\mathrm{l}=$ litter; $\mathrm{Kg}=$ Kilogram; $\mathrm{m}=$ meter; Intrac $=$ Intracellular; Extrac $=$ Extracellular.

*Significant differences between basketball and futsal; $\mathrm{p}<0.05$. ${ }^{*} \mathrm{p}<0.05 ; * * \mathrm{p}<0.01 ; * * \mathrm{p}<0.001$.

$\dagger$ Significant differences between handball and futsal, $\mathrm{p}<0.001$.

$\ddagger$ Significant differences between handball and basketball, $p<0.05$. 


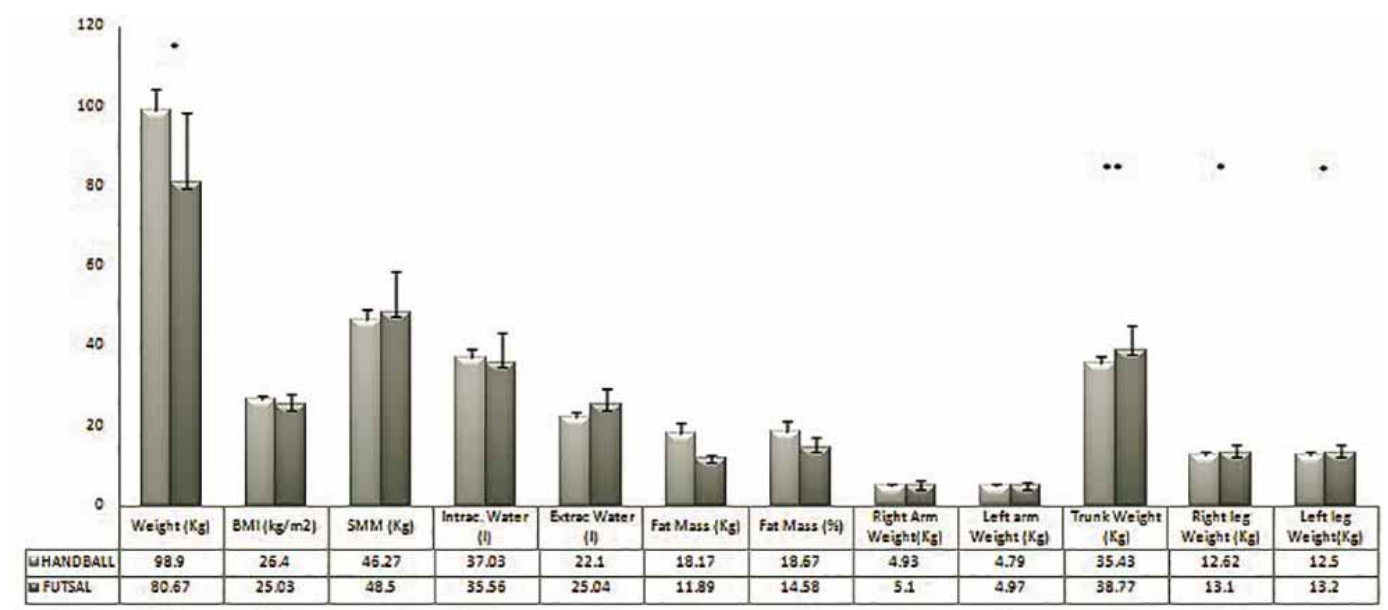

Fig. 4. Body composition of 4 group players in basketball, handball and futsal.

l= litter; Kg= Kilogram; $m=$ meter; Intrac= Intracellular; Extrac $=$ Extracellular.

*Significantly differences between handball and futsal, $*=\mathrm{p}<0.05 ; * * \mathrm{p}=<0.001$.

\section{DISCUSSION}

The aim of the present research was to analyze the differences among playing position in basketball, handball and futsal players body composition. The initial hypothesis was partially complied once differences among playing positions were detected in handball and basketball, but not in futsal players. The main finding of this study was the normative $\mathrm{BC}$ data related with the specific playing positions in professional indoor team sports players that was related with the specific requirement of the different playing position except in futsal. Since BC did not determine the playing position in futsal, other factors as physical, technical, perceptual or cognitive factors could determine the playing position in this sport (Avelar et al.).

Body mass and height provide a first idea of the morphological player's characteristics. In handball, previous studies (Carter, 1970; Giordani Vasques et al., 2007) found similar differences between playing positions as in the present study. The heaviest and tallest players were the pivot followed by goalkeeper, wing, center and handed, also pivot obtained the highest fat mass followed by goalkeeper. Those characteristics are related to the playing position, handed and pivot need height to allow better view and body mass to take advantage over the opponent in close game actions, and goalkeeper can cover more space and easily reach the corners. Moreover, actual game strategies show the importance of a height pivot, which is increasingly more involved in the game, joint to the first line of players in which anthropometric characteristics are also fundamental to obtain advantage over the opponents (Giordani Vasques et al.). In fact, previous authors found the importance of body mass in handball analyzing different national leagues, reaching the highest performance the heaviest players (Moncef $e t a l$.).

Regarding basketball, values of height, body mass, SMM and fat mass were in consonant with previous studies conducted in ACB league players (Tarrega \& Canda, 2009). Especially values of height and body mass are quite related with performance, as previous studies that found that players in lower level leagues presented lower height and lower body mass than players in ACB (Cormery et al., 2008; Drinkwater et al., 2007; Tárrega \& Canda, 2009). Specifically, we found that outside playing positions or near to the perimeter were similar than previous studies of body composition in basketball (Moncef et al.; Sallet et al., 2005). Body mass and height of point guard, shooting guard and small forward were similar to previous studies (Moncef et al.; Sallet et al.), however body mass and height of power guard and center were higher than values reported by Sallet $\mathrm{et} \mathrm{al}$. Those results suggest a tendency to increase the body mass of players, especially SMM that would facilitate the action games conducted in this area of the basketball court.

The highest body mass and percentage of body fat in football player were reached by pivots, followed by goalkeepers, back and wings. These data are consistent with similar studies in Brazilian players (Ferreira et al.), where the goalkeepers presented the highest values of body mass and body fat, followed by fix, pivots and wings. Regarding SMM, another study conducted in Brazilian elite players 
(Avelar et al.) found the highest SMM in goalkeepers, results opposite to the present study because of goalkeepers presented the lowest SMM. In addition, percentage of fat in this study (Ferreira et al.) ranging from $9.1 \%$ of midfielders and $9.9 \%$ of forwards, values lower than obtained in the present study (13.57 and $16.45 \%$ respectively), probably because of the morphological differences between countries. The differences in fat mass found in both studies are largely attributed to the game actions performed in each playing positions, finding the lower percentage of fat in positions in which an excess of fat mass acts as a dead body mass in activities where the body mass must to be repeatedly lifted (Reilly, 2006). We expected significant differences in body composition between different futsal playing position, especially because of the goalkeeper's game actions, as jumps and short trips, differed to the game action of field players, as sprint and fast direction changes (Soares \& Tourinho, 2006). The lack of significant difference, could be because of playing positions in futsal are more variable during the game due to the rotating positions system in which players begin a game action in their natural position and after that the dynamics of the game cause changes in the position and game actions, requiring the player to perform game actions typical for other playing positions.

We also found specific BC characteristics depending on the sport discipline. There are significant differences in arms, legs and trunk mass between sports in the different playing position analyzed, with futsal players being the athletes with higher mass in arms, legs and trunk, except in group 3, in which basketball's player presented the higher trunk mass. Therefore, the specific game actions in each sport require a specific body composition, showing different $\mathrm{BC}$ characteristics depending on the sport and the playing position. Also, we observed a muscle imbalance in the three sports analyzed based on the technique and dominance of players. Regarding basketball players, a tendency to increase the right leg and right arm mass was observed. This fact was related to the player's dominance, because most of them were right-handed and the launch was performed with the right arm and the impulsion when they jumped were conducted with the right leg, causing an increase in muscle mass to could perform a power, completely firm and stable jump (Moreno et al., 2008). In handball an increase in the right leg mass in left-handed players and the left leg in right-handed players was found due to the technical action of launch. However, futsal players presented the highest legs mass due to the higher sprints, fast change on move directions and the impact of legs with the ball in passes, throws, controls, these continuous impact increase the leg SMM of players (Calbet et al., 2001). On the opposite side, group
3 of basketball's player presented the highest arm mass because of the importance of arms in this playing position to control the opponent, maintain the position and launch to the basket.

Previous studies suggest that numerous body composition factors such as fat mass, body mass or muscle mass have significant influence on physical performance (Carter; Moncef et al.). Therefore, the knowledge of BC and physical characteristics of athletes could give the coach information about the performance of players and could help coaches select players depending on playing position and sport. Furthermore, this information could be considered as auxiliary elements in the talents detection programs (Hoare).

The present study provides normative $\mathrm{BC}$ data for individual playing positions of professional basketball, handball and futsal players. Principal game actions strongly affect the players BC in basketball and handball, showing basketball player's higher muscle mass in right arm and leg because they conduct the launching and jumping actions with these body extremities; and handball players present an increase in the right leg mass in left-handed players and an increase in left leg in right-handed players because of the movements performed in launching game actions. By contrary, futsal players did not present any significant differences among playing positions, possibly because of playing positions in futsal are highly variable during the game due to the player rotation positions system that require that each player to perform specific game actions, different than its specific game actions to continue the movements of rotation tactical system. It is worthwhile noting that the goalkeeper sometimes also plays as field player and for this reason also this position did not present differences in body composition with other playing positions.

Consequently, coaches could use this information to determine the type of $\mathrm{BC}$ features that are in consonant to each specific playing position and also the conditioning coach to design specific training programs depending on the playing position of each individual player. Furthermore, BC could be modified by training and diet, being a very useful tool to make nutritional and dietary changes, supplementation strategies and also calculating the right training workload. Also the normative data obtained could be a useful tool in indoor team sports talents detection programs.

Body composition in indoor team sports depend on the playing position and the sport discipline, being the body composition results of the specific game actions of each playing position. 
RAMOS-CAMPO, D. J.; MARTÍNEZ-SÁNCHEZ, F.; ESTEBAN-GARCÍA, P.; RUBIO-ARIAS, J. A.; BORES, C. A.; CLEMENTE-SUAREZ, V. J. \& JIMÉNEZ-DIAZ, J. F. Body composition features in different playing position of professional team indoor players: basketball, handball and futsal. Int. J. Morphol., 32(4):1316-1324, 2014.

RAMOS-CAMPO, D. J.; MARTÍNEZ-SÁNCHEZ, F.; ESTEBAN-GARCÍA, P.; RUBIO-ARIAS, J. A.; BORES, C. A.; CLEMENTE-SUAREZ, V. J. \& JIMÉNEZ-DIAZ, J. F. Características antropométricas en función del puesto en jugadores profesionales de equipo: baloncesto, balonmano y fútbol sala. Int. J. Morphol., 32(4):1316-1324, 2014.

RESUMEN: El objetivo fue analizar la composición corporal (CC) y sus diferencias entre demarcaciones en jugadores profesionales de baloncesto, balonmano y fútbol sala. Se analizó la CC en 70 jugadores profesionales de equipos divididos en 4 grupos en función de su demarcación: grupo 1, bases, cierres, o centrales/extremos; grupo 2, escoltas/aleros, alas o laterales; grupo 3: ala pívot/pívot, pívot y pivote; y grupo 4: porteros. Existen diferencias significativas entre las diversas demarcaciones en baloncesto en el peso, la talla, las proteínas y minerales y en el peso de brazos, piernas y tronco. En balonmano, existen diferencias significativas entre los centrales /extremos y los pívot en el peso y la masa muscular, y entre los laterales y los porteros en el porcentaje graso. También se encontraron diferencias en el peso entre las diferentes posiciones entre los tres deportes y en el peso de brazos, piernas y tronco entre los grupos 1 y 2 , y en el peso del tronco y la talla en el grupo 2. El grupo 3 presenta diferencias significativas entre fútbol sala y baloncesto en masa muscular y peso del tronco y entre baloncesto y balonmano en el peso de la pierna izquierda y el peso. En el grupo 4 existen diferencias en el peso, la altura y el peso de tronco y pernas entre fútbol sala y balonmano. La CC en los deportes de equipo estudiados depende de la posición y del deporte practicado, modificándose la CC en función de las acciones específicas del juego en cada demarcación.

PALABRAS CLAVE: Masa grasa; Talla; Rendimiento peso.

\section{REFERENCES}

Avelar, A.; Meneguzzi dos Santos, K.; Serpeloni Cyrino, E.; Olivera Carvalho, F.; Mendes Ritti Dias, R.; Altimari, L. R. \& Gobbo, L. A. Anthropometric and motor performance profile of elite futsal athletes. Rev. Bras. Cineantropometria Desempenho Hum., 10(1):76-80, 2008.

Calbet, J. A.; Dorado, C.; Díaz-Herrera, P. \& Rodríguez-Rodríguez, P. High femoral bone mineral content and density in male football players. Med. Sci. Sports Exerc., 33(10):1682-7, 2001.

Carter, J. E. The somatotypes of athletes--a review. Hum. Biol., 42(4):535-69, 1970.

Chaouachi, A.; Brughelli, M.; Levin, G.; Boudhina, N. B.; Cronin, J. \& Chamari, K. Anthropometric, physiological and performance characteristics of elite team-handball players. J. Sports Sci., 27(2):151-7, 2009.

Drinkwater, E. J.; Hopkins, W. G.; McKenna, J.; Hunt, P. H. \& Pyne, D. B. Modelling age and secular differences in fitness between basketball players. J. Sports Sci., 25(8):869-78, 2007.

Ferreira, A. P.; Gomes, S. A.; Landhwer, R. \& França, N. M. Anaerobic power and fatigue index of the Brazilian futsal team athletes. Rev. Bras. Futebol, 2(1):60-9, 2009.

Gibson, A. L.; Holmes, J. C.; Desautels, R. L.; Edmonds, L. B. \& Nuudi, L. Ability of new octapolar bioimpedance spectroscopy analyzers to predict 4-component-model percentage body fat in Hispanic, black, and white adults. Am. J. Clin. Nutr., 87(2):332-8, 2008.

Giordani Vasques, D.; Da Silva Duarte, M. F. \& Da Silva Lopes, A. Morfology of young handeball players. Rev. Bras. Cineantropometria Desempenho Hum., 9(2):127-33, 2007.
Hoare, D. G. Predicting success in junior elite basketball players-the contribution of anthropometic and physiological attributes. J. Sci. Med. Sport, 3(4):391-405, 2000.

Lamonte, M. J., McKinney, J. T.; Quinn, S. M.; Bainbridge, C. N. \& Eisenman, P. A. Comparison of physical and physiological variables for female college basketball players. J. Strengh Cond. Res., 13(3):264-70, 1999.

Moncef, C.; Said, M.; Olfa, N. \& Dagbaji, G. Influence of morphological characteristics on physical and physiological performances of tunisian elite male handball players. Asian J. Sports Med., 3(2):74-80, 2012.

Moreno, R.; Mendizabal, S.; Ramos, D. J.; Rubio, J. A. \& Jiménez, J. F. Stabilometry and body composition analysis in professional players from different sports. Arch. Med. Dep., 35(128):487, 2008.

Popovic, S.; Akpinar, S.; Jaksic, D.; Matic, R. \& Bjelica, D. Comparative study of anthropometric measurement and body composition between elite soccer and basketball players. Int J. Morphol., 31(2):461-7, 2013.

Porta, J.; González, J. M.; Galiano, D.; Tejedo, A. \& Prat, J. A. Valoración de la composición corporal. análisis crítico y metodológico. Car News, 7:4-13, 1995.

Reilly, T. Fitness assessment. In: Reilly, T. (Ed.). Science and Soccer. London, E. \& F. Spon., 1996. pp.25-50.

Sallet, P.; Perrier, D.; Ferret, J. M.; Vitelli, V. \& Baverel, G. Physiological differences in professional basketball players as a function of playing position and level of play. J. Sports Med. Phys. Fitness, 45(3):291-4, 2005. 
RAMOS-CAMPO, D. J.; MARTÍNEZ-SÁNCHEZ, F.; ESTEBAN-GARCÍA, P.; RUBIO-ARIAS, J. A.; BORES, C. A.; CLEMENTE-SUAREZ, V. J. \& JIMÉNEZ-DIAZ, J. F. Body composition features in different playing position of professional team indoor players: basketball, handball and futsal. Int. J. Morphol., 32(4):1316-1324, 2014.

Shafer, K. J.; Siders, W. A.; Johnson, L. K. \& Lukaski, H. C. Validity of segmental multiple-frequency bioelectrical impedance analysis to estimate body composition of adults across a range of body mass indexes. Nutrition, 25(1):25-32, 2009.

Silvestre, R.; West, C.; Maresh, C. M. \& Kraemer, W. J. Body composition and physical performance in men's soccer: a study of a National Collegiate Athletic Association Division I team. J. Strength Cond. Res., 20(1):177-83, 2006.

Soares, B. \& Tourinho Filho, H. Analyis of movements distances and intensitiesduring a futsal game, differences between rol positions. Rev. Bras. Educ. Fis. Esport, 20(2):93-101.

Sun, G.; French, C. R.; Martin, G. R.; Younghusband, B.; Green, R. C.; Xie, Y. G.; Mathews, M.; Barron, J. R.; Fitzpatrick, D. G.; Gulliver, W. \& Zhang, H. Comparison of multifrequency bioelectrical impedance analysis with dual-energy X-ray absorptiometry for assessment of percentage body fat in a large, healthy population. Am. J. Clin. Nutr., 81(1):74-8, 2005.

Tárrega, L. \& Canda, A. Body composition of basketball. In. Drobnic, F., Puigdellivol, J \& Bové, T. (Eds.). Scientific bases for health and optimal performance in basketball. Barcelona, Ergon, 2009. pp.20-31.

Vila Suárez, M. H.; Ferragut, C.; Alcaraz, P. E.; Rodríguez Suárez, N. \& Cruz Martínez, M. (2008). Anthropometric and strength characteristics in young handball players by playing positions. J. Arch. Sport Med., 25(125):167-77, 2008.

Villa, J. G.; Vaquera, A. \& Rodríguez, J. A. (2009). Analysis and energetic requeriments in basketball. In: Drobnic, F.; Puigdellivol, J. \& Bové, T. (Eds.). Scientific bases for health and optimal performance in basketball. Barcelona, Ergon. 1999. pp.1-19.

Wallace, M. B. \& Cardinale, M. Conditioning for team handball. Strength Cond., 19(6):7-12, 1997.

Wang, Z. M.; Heshka, S.; Pierson, R. N. Jr. \& Heymsfield, S. B. Systematic organization of body-composition methodology: an overview with emphasis on component-based methods. Am. J. Clin. Nutr., 61(3):457-65, 1995.

Williams, D. P.; Going, S. B.; Milliken, L. A.; Hall, M. C. \& Lohman, T. G. Practical techniques for assessing body composition in middle-aged and older adults. Med. Sci. Sports Exerc., 27(5):776-83, 1995.
Correspondence to:

Domingo Jesús Ramos Campo, Ph. D. Laboratory of Performance and Sport Rehabilitation Faculty of Sports Science University of Castilla la Mancha

45071. Toledo

SPAIN

Email:domingojesusramos@gmail.com

Received: 15-02-2014

Accepted: 16-09-2014 